\title{
War Films in a University Library
}

Mr. Metzdorf and Miss Oemisch, of the University of Rochester Library staff, describe a film service operated by a library.

N ALMOST EVERY CASE in which a uniI versity has established a film library, the project is under the direction of the extension division, usually as a branch of the visual aids section. In a very few instances, including the University of Denver, the Rhode Island State College, the University of West Virginia, and the University of Rochester, a university library has set up the film service; and it is to tell the story of the first year's operation of such a library project that this article has been prepared.

In January 1943 the University of Rochester sponsored a conference on Latin America. Plans for this meeting were begun in the fall of 1942 . University officials directing the program consulted the Office of the Coordinator of InterAmerican Affairs and arrangements were made to borrow ten films on Latin America for distribution in the Rochester area, five films to arrive on December $I$ and five more on December 15 . The university library was asked to handle the bookings for this material. The library had already prepared exhibits and reading lists for the conference, and to take care of requests for films did not appear to be a task which would require a great amount of time.

But we reckoned without the power of the press. A short article describing the films was carried by each daily paper and was picked up by many newspapers in nearby towns. This story emphasized that there was no charge for borrowing the prints and that they would be loaned to any responsible civic group in Western New York.

The Rochester Board of Education has fostered one of the most progressive programs of visual education in the country; many schools in the area have $16 \mathrm{~mm}$. sound projection units. The fact that Rochester is a center for the manufacture of this type of equipment means that there are more than the usual number of projectors available in this locality. These were facts we had not considered, and therefore we were surprised by the sudden rush of requests for the Latin American films. In the first two weeks of December the five films on hand were shown seventeen times to a total audience of 2254 and the advance bookings were very heavy. It became clear that a staff member would have to be delegated to do little else than arrange bookings, manage the shipping, and jog the elbows of delinquent borrowers. It also became clear that the use of films would be one of the most active phases of the Latin American conference; the Coordinator was therefore requested to send more material as soon as possible. That was our first call for help to R. C. Maroney, director of distribution for the C.I.A.A., and, like all calls since, it was not unheeded. Additional blocs of films were announced for January distribution, 
and by the time the Rochester conference was held at the end of January twentyfour thousand persons had seen the fifteen films on deposit.

It was expected that after the conference the films would be returned to New York and the library would revert to its normal routine. But reservations for films and requests for new material continued to pour in, and it was decided to accept these bookings on a tentative basis. All unwittingly, we had caught a bear by the tail!

\section{Inception of Service}

Here was a war service for which there was great demand and one which the library could supply without any disruption of its regular work. After studying the matter, the university decided to set up a film library on a small scale and to let the project grow or die according to the apparent need for such a service. This would be a natural expansion of the already established war information center in the library. No charge except transportation costs had been made for the Latin American films, and it was decided to continue operations on this basis, at least for a time. It was also decided to limit the collection to $16 \mathrm{~mm}$. sound films. The few financial requirements of the service would be met from general library funds, and staff time would be allocated according to need.

Such was the genesis of the Educational Film Service of the University of Rochester Library. The child grew. By the end of February, one month after the conference, thirty-nine thousand people had seen the C.I.A.A. films and 193 showings had been held. The saturation point was beginning to draw near, and other film sources were investigated.
Since the university library could not afford to purchase any extensive number of prints, it was necessary to acquire films by deposit or gift. The Latin American films had met with a wide demand, but the reaction to material of a more general nature and to films in other specialized fields could not be gauged. Other film libraries might be supplying such material in sufficient quantity, and the demand might be negligible.

Events proved that there was room for another film center in Western New York. In Rochester the Eastman Kodak Company and the John Allen Company maintain extensive libraries, and in the central part of the state Syracuse University operates a film center. Some films are also available in Ithaca and Buffalo. Most of these other services, however, are established on a rental or service fee basis, and it may have been on this score that the field of operations was found to be wide open to a free distribution center which would not compete with commercial libraries.

\section{Campaign for Films}

Before any money was spent for equipment, a lively letter campaign was begun to solicit films for the collection. Our first gift came from the Free French Delegation in New York City, and the United China Relief followed with a print of "Western Front." Fruitful advice on the subject of possible sources of films was received from $L$. C. Larson, of Indiana University (who may be considered the godfather of our project), George Janecek, of the United Nations Information Service, and T. Y. Lo, of the Chinese government film organization. Encouragement and helpful suggestions from a committee of trustees appointed by the 
president of the university have always been forthcoming.

Although the supply of film stock had been severely reduced by the war, official groups and industrial organizations were most generous in depositing prints of available films. The United States Rubber Company, the General Electric Company, the Caterpillar Tractor Company, the International Harvester Company, the American Brass Company, the Carborundum Company, the New York Central System, and the National Association of Manufacturers all sent prints, and all of the prints were called for by the public. The C.I.A.A. continued to supplement the original bloc of Latin American films, and new requests for bookings were received daily. By the end of May 1943292 showings had been recorded to a total audience of 52,654 .

The educational film service settled down to a less hectic summer season, and plans were laid for further development. A room next to the library lecture room was fitted up with tables, chairs, and a range of steel shelves. A rewinder, a splicing outfit, and other pieces of standard equipment were acquired. The lecture room itself was fitted out with a large beaded screen, and arrangements were made with one of the teaching departments for the use of a sound projector; community groups were thereby enabled to reserve the room for meetings at which films from the collection could be shown. The facilities also made it easy to preview films and decide quickly about their suitability. Frantic studying of instruction manuals and a diligent course in reading were followed by those to whom care of the service had been delegated. The library had joined the Educational Film Library Association when that organiza- tion was formed, and the results of this membership have been most gratifying. Advice from the American Film Center proved to be of great value, as did consultations with the Harmon Foundation and the New York University Film Library. Officials of the Eastman Kodak Company were very helpful in supplying technical advice, and when the film workers did not know enough to ask for advice, experience proved a ready teacher. The mysteries of this new type of library service soon unfolded, and we felt that we had a fairly professional setup with which to work.

\section{Publicity}

A leader identifying each film as coming from the Educational Film Service was designed, and a copy attached to every print. A general publicity program was mapped out, consisting of news stories and the preparation of a bulletin about the activities of the service. For this latter project, a mailing list of about five hundred names in the Western New York area was prepared and addressograph plates were made. This list is being added to every week.

At the end of the first year of operations, the work of the film service was surveyed and evaluated. Six films had been purchased to round out various branches of the collection, and these, together with equipment and other incidental costs (excepting the contribution of staff time), accounted for an expenditure from general funds of about $\$ 350$.

To show for this expense, the university library had on Jan. I, I944, a film collection of 109 prints which had been shown $87 \mathrm{I}$ times during the year to 177 different organizations. The audience total for the period was I09,569. Of the 
Io9 prints, forty-seven were from the Coordinator of Inter-American Affairs, twenty-eight from the several information bureaus of the United Nations, eighteen from industrial organizations, twelve from the O.W.I., and four from the O.C.D.

The film library was designed from the beginning as a public service feature, the primary object of which was to bring to Western New York nontheatrical audiences, at no charge, all obtainable films dealing with the war effort, as well as any other educational films of general interest. Groups which previously have had little contact with the university have made regular use of the films, and the distribution has ranged from the Junior League to a migrant workers' camp, from the Chamber of Commerce to the Labor Lyceum. All shades of religious orthodoxy have been represented and all levels of public instruction. Borrowing groups are extremely appreciative of the free film service, and evidence of careful handling of the films lies in the fact that very little repair work has been necessary. From the point of view of the library, the project has proved extremely worth while: it has brought us in touch with many new friends and it has supplied material of proved educational value to a large number of citizens. 